Doi: https://doi.org/10.31578/jebs.v6i1.222

\title{
Pre-Service Teachers' Perceived Level of Teaching Skills
}

Iris April L. Ramirez*

\begin{abstract}
To enable pre-service teachers acquire certain teaching skills, well-planned educational programs and well-trained teachers are needed to implement them. Indeed, teacher education institutions hold a major responsibility in training qualified pre-service teachers, as it is essential for the welfare of a country and securing the quality of all educational levels from primary to tertiary education. To determine the level of teaching skills, a qualitative descriptive method was used with 96 pre-service teachers. The study adopted and modified a scale according to the needs of the study and validated by experts. The present study found that the pre-service teachers of Bukidnon State University (BukSU) generally are prepared for classroom work as revealed in the results of their internship in the laboratory school (which serves as the training ground where the education students of the University have their pre-service teaching) as well as during their off-campus experiences which consist of their roles as student interns and their ability to handle students' participation. Qualitative research methods can be resorted in order to perform in-depth descriptive studies to investigate the differences in the teaching skills of pre-service teachers from different indicators.
\end{abstract}

Keywords: pre-service teachers, teaching, skills, teacher education, internship

\section{Introduction}

The most important role of teacher education institutions in the educational system is to prepare pre-service teachers to be equipped with certain teaching skills. Teacher quality is a complicated concept, although qualities of teachers are categorized in various ways in the literature. It is critical to note that these qualities should be regarded as a whole, with each having complementary features. To enable pre-service teachers, acquire certain teaching skills, well-planned educational programs and well-trained teachers are needed to implement these programs. While philosophies, approaches, and practices adopted in education tend to change the role of the teacher, they have never undermined it. Indeed, teacher education institution hold a major responsibility in training qualified pre-service teachers as it is essential for the welfare of a country and securing the quality of all educational levels from primary to tertiary education.

Teachers who are deemed as professionally competent must demonstrate that they can teach successfully: can do effective planning, monitoring and evaluation for learning and manage the teaching curriculums according to the needs of individuals and groups within the classroom (TED, 2009). The necessity of a teacher's expertise in their field and having the professional teaching knowledge that will enable them to pass on their knowledge and skills to students is believed to hold importance as to ensure quality in education. The teachers' sense of competence is said to be very important in the success of learning and teaching activities and in the motivation of students to learn (Sünbül \& Arslan, 2009). It is stated that the quality of teacher training has a direct influence not only on the development of children's knowledge, but also in the shaping of their personalities, especially during the early years of their education (European Parliament, 2008).

*Malaybalay City, Bukidnon, Philippines, orcid.org/0000-0002-8616-4510 
According to Salandanan (2012), teaching is a multifarious human activity. As an activity, it encompasses various aspects, including planning, strategies, organizational structure, and material resources which simultaneously occur during the process of teaching and learning. Teaching is perceived as stimulating, directing, guiding the learner, and evaluating the learning outcomes of teaching. Contemporary teacher's role in teaching has become more complex but it has given the learner the responsibility of learning (Bilbao et al., 2012). Bilbao et al. (2012) added that teaching requires from practitioners to understand what must be carried out to affect student learning and be well-equipped with the skills needed to perform various tasks.

In this context, teaching internship is an essential component of teacher training. It is actually the culminating experience that broadens and enhances the capability of the pre-service teachers who must cope with the multi-faceted responsibilities of teaching (Zeichner, 2002). In other words, it serves as the training of students in real world scenario, as they put into practice the educational theories and philosophies, teaching approaches and strategies and instructional technologies that they significantly learned in their professional education learning areas. In view of that, a quality teacher training could be evident through the lens of the teaching skills and performance of the pre-service teachers.

Sustainability in the workforce as it relates to education means that pre-service teachers are prepared to face the realities of teaching (Williams et al., 2016). Multiple studies show that the teacher is a key player in the success of the individual student in the classroom (Bricker, 2000; Pijl \& Frissen, 2009 as cited in Gedzune, 2015; Silverman, 2007). Developing this professional state of mind has significant implications for teacher education institutions as they attempt to identify the dispositions needed by educators in the day-to day life of a school. According to the United Nations Decade of Education for Sustainable Development Initiative, the goal of sustainability is to create a world where every a child has the opportunity to benefit from a quality education (Strode, 2013).

However, teacher educators who train pre-service teachers should also display effective teaching and reflect on the sequence and consequence of their teaching, and to facilitate the assimilation between theory and practice through field teaching experience (Amobi \& Irwin, 2009). Also, according to Beltran as cited by Mazo (2015), the success of practice teaching largely depends on the personal and social qualities of pre-service teachers. Its success also depends on how well pre-service teachers are trained by cooperating teachers in teaching effectively, managing the class, disciplining the learners, and performing other related functions. This explains why cooperating teachers who are designated to assist pre-service teachers must also possess the competencies required in honing the pre-service teachers' pedagogical skills (Laruan, 2006).

Hence, in order to figure out whether the college of education relevantly prepared the pre-service teachers' for their jobs, this study was conducted to investigate the level of teaching skills in terms of lesson planning, pedagogical skills, communication skills, and classroom management of pre-service teachers in the Teaching Internship. In essence, the results of this study may be used to form recommendations that may specifically guide the teacher education institutions in their curriculum enhancement and policy-making, geared toward quality instruction.

\section{Research Goals}

The purpose of this study was to assess the teaching competence of the secondary pre-service teachers. Specifically, the study attempted to determine the level of teaching skills in terms of:

a. lesson planning,

b. pedagogical skills, 
c. communication skills, and

d. classroom management.

\section{Research Methodology and Procedure}

\section{Method}

To determine the level of teaching skills, a quantitative descriptive method was used. The design was appropriate because the intention was to describe the teaching skills of the pre-service teachers after the teaching practice.

\section{Locale}

The study was conducted at the Bukidnon State University. The said school is located at the heart of Malaybalay City, Bukidnon. It is one of the leading educational institutions serving the people not only in Mindanao, but also the whole country. Bukidnon State University offers varied programs of academic excellence along with diverse opportunities. Students can participate in relevant internship at local and international level, field experiences, and community service and leadership development. It is also known as a major supplier of teachers not only in the province, but also throughout the region. Rigorous improvements are aligned to address the global perspective of the University. The school was primarily a teacher education institution during its establishment years, it provided Laboratory Schools for its Bachelor in Elementary Education and Bachelor of Secondary School courses. The laboratory schools served as the training ground where the education students of the University have their preservice teaching.

\section{Participants}

The participants for the study included the 96 Pre-service Teachers (PST) enrolled at the Bukidnon State University taking up Bachelor of Secondary Education major in Biological Sciences (8), English (18), Filipino (16), Math (10), Social Studies (19), and BPE-SPE (25) during the $2^{\text {nd }}$ semester of the school year 2018-2019. This group of Pre-service teachers consisted of senior undergraduate students. They had a 9-week off-campus pre-service teaching at BukSU - Secondary School Laboratory.

A stratified random sampling technique was used. It is a probability sampling technique where the population is divided into strata (or subgroups) and a random sample is taken from each subgroup. The subgroups were based on the major field that the pre-service teachers were taking. Its purpose is to ensure that every stratum is adequately represented.

\section{Instrument}

To determine the level of teaching skills of the pre-service teachers, the study adopted the instrument from Ramirez (2019) which was modified according to the needs of the study. The said instrument underwent a validation by experts from three professors of different universities in Cebu City, Philippines.

The teaching skill was subdivided into four parts. Each subdivision was composed of 15 statements that determine the level of teaching competence of the PST in terms of teaching skills, specifically on Lesson Planning, Pedagogical Skills, Communication Skills, and Classroom Management, respectively. A five-point Likert scale - very high (5), high (4), average (3), poor (2), and very poor (1) - was applied.

Table 1. Mean Intervals and Description of Level of Teaching Skills 


$\begin{array}{cccc}\text { Rating } & \text { Mean Range } & \text { Performance } & \text { Level of Competence } \\ 5 & 4.20-5.00 & \text { Very High } & \text { Very High } \\ 4 & 3.40-4.19 & \text { High } & \text { High } \\ 3 & 2.60-3.39 & \text { Average } & \text { Moderate } \\ 2 & 1.80-2.59 & \text { Poor } & \text { Low Low } \\ 1 & 1.00-1.79 & \text { Very Poor } & \text { Very Low }\end{array}$

\section{Data Gathering Procedure}

The researcher gathered all the secondary pre-service teachers for a short briefing stating the purpose of the research. Also, the consent of these PSTs were asked before gathering the raw data. After informing the respondents about the source of data collection, participation risks and benefits, voluntary participation and withdrawal, as well as its confidentiality, the researcher agreed on a schedule with the respondents concerning where and when to conduct the survey. During the actual data collection, the pre-service teachers were given the questionnaire. The researcher herself presented and collected the data. To prevent any data loss, the questionnaires were directly collected from the pre-service teachers as soon as they were done.

\section{Findings and Discussion}

\section{Level of Teaching Skills in terms of Lesson Planning}

The level of teaching skills of pre-service teachers after the teaching practice in terms of lesson planning is presented in Table 2 .

Table 2. PSTs Perceived Level of Teaching Skills in terms of Lesson Planning

\begin{tabular}{|c|c|c|c|}
\hline & INDICATORS & Mean & Description \\
\hline \multirow{2}{*}{$\begin{array}{c}\text { Overall Plan } \\
1\end{array}$} & & 4.52 & Very High \\
\hline & Written in a clear and understandable manner & 4.46 & Very High \\
\hline 2 & Practical (can be carried out in an actual school situation) & 4.42 & Very High \\
\hline 3 & Geared to the level of the students for which it was prepared & 4.54 & Very High \\
\hline 4 & Includes the use of supportive or illustrative audio or visual aids & 4.66 & Very High \\
\hline \multicolumn{2}{|c|}{ Preliminary Material } & 4.54 & Very High \\
\hline 5 & $\begin{array}{l}\text { Includes a clear title for the lesson that accurately reflects the lesson } \\
\text { content }\end{array}$ & 4.68 & Very High \\
\hline 6 & $\begin{array}{l}\text { Includes resources and identification of prerequisite assignments } \\
\text { designed to prepare students for class }\end{array}$ & 4.53 & Very High \\
\hline 7 & Includes a complete list of all supplies and materials needed for the lesson & 4.41 & Very High \\
\hline Objectives & & 4.55 & Very High \\
\hline 8 & Objectives are stated in terms of student behavior & 4.45 & Very High \\
\hline
\end{tabular}


9

Objectives are clear, concise and easily understood

10

Objectives are designed to support identified student "outcomes" for the entire course as stated in the course outline

\section{Lesson Presentation}

11

Uses methods, techniques and learning experiences appropriate to the lesson objectives

12

Provides students with opportunities to become actively engaged in the learning process

13

Meets student needs, interests and abilities

\section{Content}

14

15

Content is sufficient and appropriate to the level of the students and the level of the course

Includes information necessary for the achievement of the stated objectives

4.64

Very High

4.57

4.53

Very High

Very High

4.58

Very High

4.64

Very High

4.36

4.60

Very High

Very High

4.61

Very High

4.59

Very High

The table reveals that all indicators are Very High. It may be inferred that pre-service teachers were well-equipped in terms of Lesson Planning. The relationship between the quality of a lesson plan and an effective teaching-learning process is widely acknowledged by researchers and educators (Sahin-Taskin, 2017). Thus, developing pre-service teachers' planning skills is considered a key in educating effective teachers.

Lesson planning connects requirements of the curriculum and textbooks with what is presented in the classroom (Lee, Chen \& Khum, 2009). Thus, preparing a lesson plan helps pre-service teachers to organize their activities, construct their goals, and get feedback from their supervisors (Kagan \& Tippins, 1992). Accordingly, planning is one of the crucial skills that pre-service teachers should gain during their training

Meticulous lesson planning is a deliberative process to enhance students' subject matter, self-learning and social learning. Understanding these 3Ss (subject matter, self-learning and social learning) is very important in the lesson planning process (Henderson \& Gornik, 2007). According to Henderson and Gornik (2007), the teacher is expected to consider the relativeness of the course design, course planning, and unit/lesson planning while designing the lesson plan. Effective teaching can be done only with effective planning. So, lesson planning is the key to successful teaching. Just filling the details in a given template is not lesson planning. It is a creative art to pour out the unique thoughts of individuals. Thus, planning for classroom teaching is one of the significant skills that pre-service teachers must gain during their training period.

Also, the results of the research show that in the lesson planning, content has the highest mean (4.60), which is Very High. The result may indicate that, from the beginning of their formation as pre-service teachers, they were equipped with the content knowledge necessary for them to teach effectively. The obtained results further revealed that pre-service teachers may have knowledge of the substance and nature of the subject matter they teach and that the schools are shaping and producing quality pre-service teachers.

Teachers gain their knowledge for teaching from various sources (Grossman, 1990); the same can be expected to apply to teacher knowledge of subject matter. Drawing on Grossman's research, Friedrichsen et al. (2009) distinguished three potential sources of subject-matter knowledge: (a) teachers' own K-12 learning experiences, (b) teacher education and professional 
development programs, and (c) teaching experiences. Formal learning opportunities are organized and structured by teacher education institutions on the basis of learning objectives; they may generally lead to qualifications. Formal learning is mainly intentional-that is, the learner has the explicit objective of acquiring knowledge and skills.

\section{Level of Teaching Skills in terms of Pedagogical Skills}

The level of teaching skills of pre-service teachers after the teaching practice in terms of pedagogical skills is presented in Table 3.

Table 3 PSTs Perceived Level of Teaching Skills in terms of Pedagogical Skills

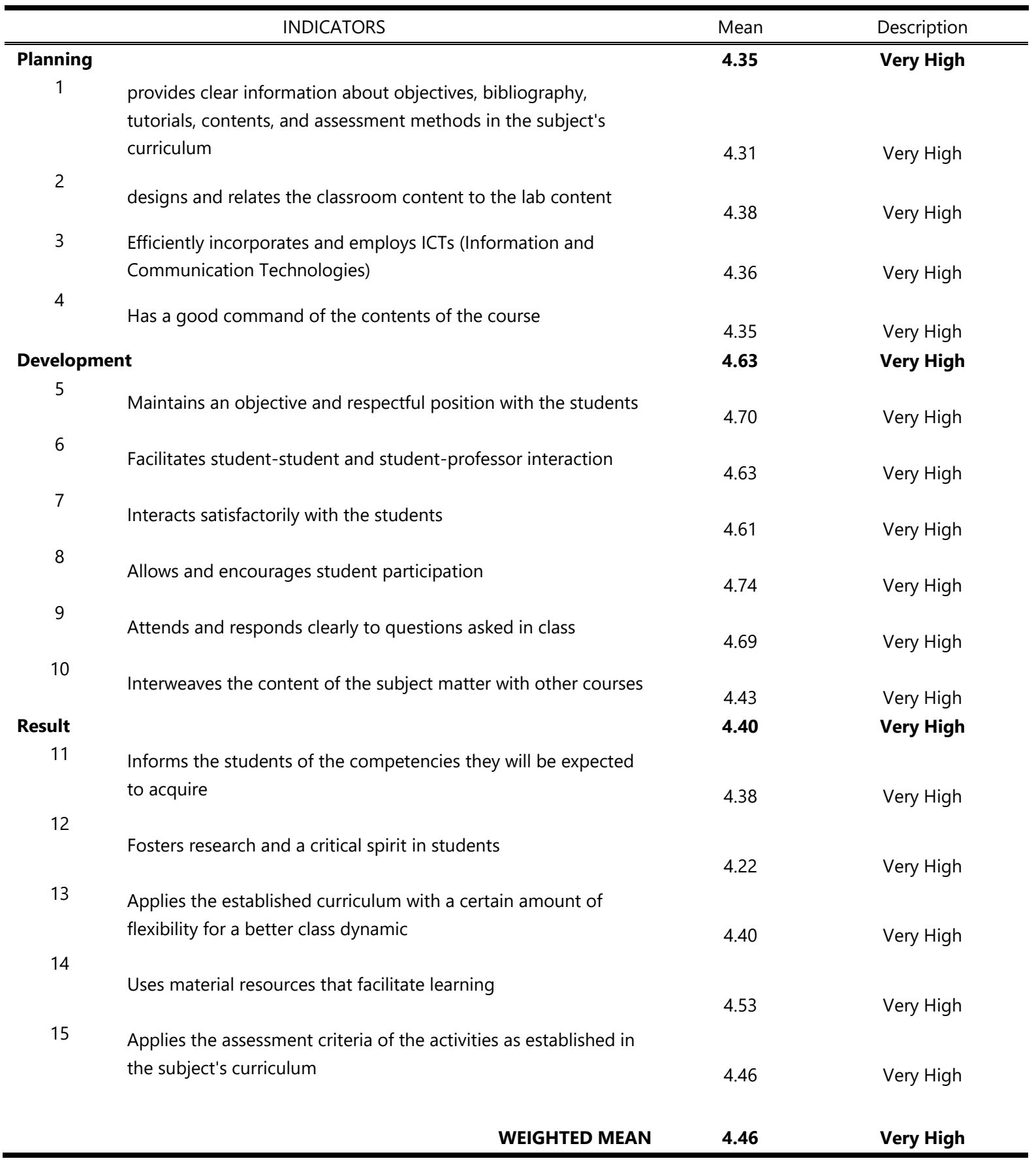


From Table 3 it can be seen that the overall weighted mean is Very High. This perception could have arisen from personal experience as interns in schools, causing them to feel that they know what teaching is about. It can also be perceived that preservice teachers have some pre-requisite pedagogical skills. It has been revealed that overall, pre-service teachers showed a very positive response. Teaching internship may have played an integral part in the growth of pre-service teachers and their pedagogical skills. Also, the initial teacher preparation and internship programme may have had a positive effect on their perceptions. Thus, the ability to teach effectively depends on the teachers' perceptions of knowledge and skill, and knowledge and skill occurs in a variety of forms.

According to key theorists, pedagogical views are shaped by pre-service teachers' own experiences; they align closely with beliefs about knowledge, how students learn and how teachers teach (Ryan et al., 2009). Wrench and Garrett (2012) also revealed that particular pedagogical practices are adopted from pre-service teachers' own experiences and influenced by technical rationality, performance pedagogies and shaped by learning from core education subjects. In constructing new beliefs, the preservice teacher must link theory to practice within existing preconceptions (Wubbels, 1992), allow opportunities for critical reflection (Endacott \& Sturtz, 2015) and a deeper analysis of pedagogical reasoning (Vosniadou et al., 2008). Wrench and Garrett (2012) indicated that the pre-service teachers 'make strategic decisions', when teaching supported their own pedagogical interests.

The pre-service teachers' exposure to the realities of the classroom created connections between their existing and new pedagogical skills. Thus, the understanding of these teaching skills is crucial, as the data derived may help teacher education programs to redesign the courses offered, so as to be able to enhance the pedagogical skills among pre-service teachers.

\section{Level of Teaching Skills in terms of Communication Skills}

The level of teaching skills of pre-service teachers after the teaching practice in terms of communication skills is presented in Table 4.

Table 4 PSTs Perceived Level of Teaching Skills in terms of Communication Skills

\begin{tabular}{clcc}
\hline \multicolumn{1}{c}{ INDICATORS } & Mean & Description \\
\hline \hline $\begin{array}{c}\text { Articulation } \\
1\end{array}$ & $\begin{array}{l}\text { Teaches with lesser speech sound errors. Sounds in words are not } \\
\text { omitted, distorted, or substituted }\end{array}$ & $\mathbf{4 . 1 6}$ & High \\
2 & Words used are not consistently difficult to understand, especially when & 4.07 & High \\
the topic is not known & 4.25 & Very High \\
Voice & Speaking voice is well modulated & 4.44 & Very High \\
4 & Has no unusual voice quality (i.e. harsh/hoarse, nasal, or breathy). & 4.48 & Very High \\
Speech Fluency & 4.40 & Very High
\end{tabular}


5

No disfluencies that interfere with communication (i.e. stuttering, sound, syllable, or word repetitions, sound prolongations, blocks or abnormal hesitations, abnormal rate of speech).

6

Does not use excessive filler phrases (i.e. "um," "uh," "you know").

Does not appear to be frustrated when speaking.

4.25

Very High

Language

No difficulty in understanding age-appropriate directions.

No difficulty answering or responding to age-appropriate questions and other verbal information.

11

Speaks in complete sentences and phrases.

Oral language does not contain numerous grammatical errors that are not typical for students of the same age.

Table 4 shows that the teaching skills of the pre-service teachers in terms of communication skills is Very High. It can be inferred that communication skills of pre-service teachers were obtained not only from the teacher education process, but also from the culture. With the practice of teaching such as internship, pre-service teachers were able to hone communication skills and also build knowledge about instructional communication.

Effective communication skills ensure that each teacher gets the best from the students. The study that was conducted by Sng Bee (2012) considers that good communication skills are important not only for teachers, but also for students and their academic success. Classroom communication involves face-to-face interaction and communication that is necessary between class participants to ensure undisturbed learning process (Kazi et al., 2012). Hence, communication skills are very important and essential for each teacher, and they are the foundation of successful and quality communication with students.

It can also be observed from Table 4 that articulation has the lowest mean (4.16) which is High. This may indicate that pre-service teachers may have difficulty in using consistently the words that learners may understand, especially when the topic is not known. The findings of the study conducted by Cohort Nominate (2016) concluded that teaching is generally considered as only fifty percent of knowledge and fifty percent of interpersonal or communication skills. Thus, it is necessary for a teacher to have not only quality knowledge, but also effective communication skills. 


\section{Level of Teaching Skills in terms of Classroom Management}

The level of teaching skills of pre-service teachers after the teaching practice in terms of classroom management is presented in Table 5.

Table 5 PSTs Perceived Level of Teaching Skills in terms of Classroom Management

\begin{tabular}{|c|c|c|c|}
\hline \multicolumn{2}{|r|}{ INDICATORS } & \multirow{2}{*}{$\begin{array}{c}\text { Mean } \\
4.31\end{array}$} & \multirow{2}{*}{$\begin{array}{l}\text { Description } \\
\text { Very High }\end{array}$} \\
\hline Learnin & ronment & & \\
\hline 1 & $\begin{array}{l}\text { Distractions are minimized in the direct instruction and independent } \\
\text { work areas }\end{array}$ & 4.29 & Very High \\
\hline 2 & Students are seated and positioned to maximize focus on task & 4.28 & Very High \\
\hline 3 & $\begin{array}{l}\text { Areas of the classroom are clearly defined with visual/structural } \\
\text { parameters }\end{array}$ & 4.35 & Very High \\
\hline \multicolumn{2}{|c|}{ Instructional Strategies and Programs } & 4.42 & Very High \\
\hline 4 & $\begin{array}{l}\text { Variety of instructional strategies are being used and are based on the } \\
\text { skills being taught and the student's strengths. }\end{array}$ & 4.43 & Very High \\
\hline 5 & Direct instruction is used as necessary to teach initial acquisition of skills. & 4.43 & Very High \\
\hline 6 & $\begin{array}{l}\text { A variety of prompts are used and based on the skill being taught and the } \\
\text { individual student. }\end{array}$ & 4.40 & Very High \\
\hline \multicolumn{2}{|c|}{ Rules and Procedures } & 4.47 & Very High \\
\hline 7 & $\begin{array}{l}\text { Routines for entering, exiting, and moving within the classroom are taught, } \\
\text { reviewed and reinforced on a regular basis. }\end{array}$ & 4.48 & Very High \\
\hline 8 & $\begin{array}{l}\text { Procedures for getting help, getting a drink, going to bathroom, pencil } \\
\text { sharpening, etc. are taught, reviewed and reinforced on a regular basis. }\end{array}$ & 4.43 & Very High \\
\hline 9 & $\begin{array}{l}\text { Classroom rules regarding behavior expectations are posted, taught, } \\
\text { reviewed, and reinforced on a regular basis. }\end{array}$ & 4.50 & Very High \\
\hline \multicolumn{2}{|c|}{ Student Communication } & 4.47 & Very High \\
\hline 10 & $\begin{array}{l}\text { Students have appropriate expressive systems to initiate, request, state } \\
\text { needs, protest and make choices }\end{array}$ & 4.45 & Very High \\
\hline 11 & $\begin{array}{l}\text { The environment is set up so that students need to communicate } \\
\text { frequently }\end{array}$ & 4.51 & Very High \\
\hline 12 & Student initiated communication is responded to immediately & 4.48 & Very High \\
\hline 13 & $\begin{array}{l}\text { Students set up, complete and put away activities or are learning these } \\
\text { skills }\end{array}$ & 4.47 & Very High \\
\hline
\end{tabular}


14 goals and objectives are developed as appropriate (i.e. on task time sequences multiple tasks)

Table 5 shows that the pre-service teachers' teaching skills in terms of classroom management is Very High. It can be perceived that pre-service teachers maintained an orderly and peaceful environment while dealing with the teaching routine and also holding activities to motivate and empower the learners. This may also be due to the presence of the supervising instructors in the classroom while they were conducting their demo lessons. It is a common practice that the supervising instructors warn their classes to sit quietly before the pre-service teachers begin their demo lessons. Therefore, pre-service teachers usually teach to relatively quieter students, which resulted to a positive response.

Merç and Subaşı (2015) investigated the problems of student teachers about classroom management and how they cope with these problems. They found that problems generally come from students, the teaching point and materials, and cooperating teachers. To cope with the problems, they face, student teachers use their knowledge from methodology lessons, they get consultations from their cooperating teachers and they think about their experiences with their previous teachers.

It is a fact that classroom management is a complex process in which teacher response is a matter of philosophy and style. The teacher should be aware of some common preventive measures, explore the establishment of rules in the classroom, and have an orientation of some factors that can influence the learner's behavior. Thus, the pre-service teacher may design an approach to classroom management in a style that fits the learner's personality and instructional intentions.

\section{PSTs Overall Perceived Level of Teaching Skills}

The overall level of teaching skills of pre-service teachers is presented in Table 6.

Table 6. PSTs Overall Perceived Level of Teaching Skills

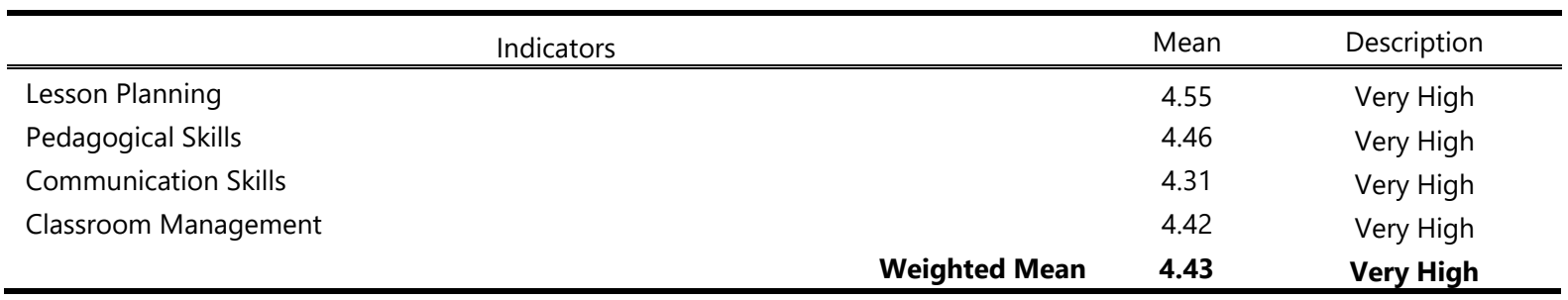

As shown in Table 6, the pre-service teachers overall perceived level of teaching skills is generally Very High. The result findings are consistent with the result, this may imply that the pre-service teachers appeared in their classes well-prepared and with wellorganized lessons. The results further indicate that BukSU is shaping and producing pre-service teachers with quality performance based on the indicators as shown in this table, thus, making them become globally competitive and allowing them to face the modern and complex society across continents with confidence. 


\section{Conclusion and Recommendations}

Teaching is a calling and a noble profession that involves immense accountability with a challenging task. It is not simply a kind of employment, but it should also be considered as a humanistic profession. Teachers are assets in building friendships, communities, and nation. Further, from the outset in the formation of future teachers, they need to realize that they have a huge responsibility in building strong and responsible citizens. The making of a teacher is an ongoing process that is developed and honed over years. Creating meaningful experiences through their internship in collaboration with their supervising instructors is therefore inevitable.

The present study found that the pre-service teachers of BukSU generally are prepared for classroom work as revealed in the results of their internship in the laboratory school as well as during their off-campus experiences which consist of their roles as student interns and their ability to handle students' participation.

Qualitative research methods can be resorted to in order to perform in-depth descriptive studies to investigate the differences in the teaching skills of pre-service teachers from different indicators. 


\section{References}

Amobi, F.A., \& Irwin, L. (2009). Implementing on-campus microteaching to elicit preservice teachers' reflection on teaching actions: Fresh perspective on an established practice. Journal of the Scholarship of Teaching and Learning, 9 (1), 27-34.

Bilbao, P.P., Lucido, P.I., Iringan, T.C., \& Javier, R.B. (2012). Curriculum development. Quezon City, Philippines: Lorimar Publishing, Inc

Bricker, D. (2000). Inclusion: How the scene has changed. Topics in Early Childhood Special Education, 20(1), 14-19.

Cohort Nominate. (2016). Communication Skill For Teachers: An Overview. Retrieved on 10/08/19 from http://www.communicationskillsworld.com/communicationskillsforteachers.html

Endacott, J. L., \& Sturtz, J. (2015). Historical empathy and pedagogical reasoning. The Journal of Social Studies Research, 39 (1), 116.

European Parliament, (2008). European Parliament resolution of 23 September 2008 on improving quality of teacher education, (2008/2068(INI)). Retrieved September 20, 2020 from https://www.europarl.europa.eu/sides/getDoc.do?pubRef=//EP//TEXT+TA+P6-TA-2008-0422+0+DOC+XML+V0//EN

Friedrichsen, P.J., Abell, S.K., Pareja, E.M., Brown, P.L., Lankford, D.M., \& Volkmann, M.J. (2009). Does teaching experience matter? Examining biology teachers' prior knowledge for teaching in an alternative certification program. Journal of Research in Science Teaching, 46, 357-383. doi:10.1002/tea.20283

Gedzune, G. (2015). Awakening pre-service teachers to children's social exclusion in the classroom. Discourse and Communication for Sustainable Education, 6, 95-109.

Grossman, P.L. (1990). The making of a teacher. Teacher knowledge and teacher education. New York, NY: Teachers College Press. Henderson, J.G. \& Gornik, R. (2007). Transformative curriculum leadership. Upper Saddle River, NJ: Pearson Education, Inc.

Kagan, D.M. \& Tippins, D.J. (1992). The evolution of functional lesson plans among twelve elementary and secondary student teachers. The Elementary School Journal, 94, 477-489.

Kazi, E.H., Abdul Razak, A.Z. \& i Mosa, F. Z. (2012). Excellent teachers and their job satisfactions: An analysis at Malaysia's standpoint. International Journal of Academic Research in Progressive Education and Development, 1(4), 1-16.

Laruan, M.J. (2006). Problems of pre-service teachers. The Modern Teacher, 1 (1), 29.

Lee Y., Chen, X., \& Khum, G. (2009). Mathematics teachers' practices and thinking in lesson plan development: A case of teaching fraction division. ZDM Mathematics Education, 41, 717-731.

Mazo, G.N. (2015). Perspectives of implementers on the Pre-service Teacher Practicum Program of a Philippine University: Inputs for program improvement. Journal of Education and Learning, 9 (4), 296-304.

Merç, A., \& Subaşı, G. (2015). Classroom management problems and coping strategies of Turkish student EFL teachers. Turkish Online Journal of Qualitative Inquiry, 6(1), 39-71. https://doi.org/10.17569/tojqi.41736

Pijl, S.J. \& Frissen, P. H. A. (2009). What policymakers can do to make education inclusive. Educational Management Administration \& Leadership, 37(3), 366-377. 
Ramirez, IAL. (2019). Teaching senior high school: through the eyes of student intern. International Journal of Multidisciplinary Approach and Studies, (6)3, 42-52.

Ryan, M., Carrington, S., Selva, G., \& Heally, A. (2009). Taking a 'reality' check: Expanding pre-service teachers' views on pedagogy and diversity. Asian-Pacific Journal of Teacher Education, 37 (2), 155-173.

Sahin-Taskin, C. (2017). Exploring pre-service teachers' perceptions of lesson planning in primary education. Journal of Education and Practice, 8 (12), 57-63.

Salandanan, G.G. (2012). Teaching and the teacher. Quezon City, Philippines: National Book Store.

Silverman, J. C. (2007). Epistemological beliefs and attitudes toward inclusion in preservice teachers. Teacher Education and Special Education: The Journal of the Teacher Education Division of the Council for Exceptional Children, 30(1), 42-51.

Sng Bee, C. (2012). The impact of teachers' communication skills on teaching: Reflections of pre-service teachers on their communication strengths and weaknesses. Humanising Language Teaching, 14 (1). Retrieved September 30, 2020 from https://old.hltmag.co.uk/feb12/mart.htm

Strode, A. (2013). Participatory action research for development of prospective teacher's professionality during their pedagogical practice. Discourse and Communication for Sustainable Education, 4, 80-90.

Sünbül, A. M., \& Arslan, C. (2009). Öğretmen yeterlik ölçeğinin geliştirilmesi ve bir araştırma örneği. Retrieved from http://tef.selcuk.edu.tr/salan/sunbul/f/f17.doc

Türk Eğitim Derneği (TED). (2009). Öğretmen yeterlikleri. Ankara: Adım Okan Matbaacılık. Retrieved from portal.ted.org.tr/yayinlar/Ogretmen_Yeterlik_Kitap.pdf

Vosniadou, S., Vamvakoussi, Z., \& Skopeliti, I. (2008). The framework theory approach to the problem of conceptual change. In S. Vosniadou (Ed.). International Handbook on Research on Conceptual Change, p. 3-34. New York: Routledge

Williams, D., Edwards, B., Kuhel, K., \& Lim, W. (2016). Culturally responsive dispositions in prosepective mathematics teachers. Discourse and Communication for Sustainable Education, 7(2), 17-33.

Wrench, A. \& Garrett, R. (2012). Identity work: Stories told in learning to teach physical education. Sport, Education and Society, 17 (1), 1-19. http://dx.doi.org/10.1080/13573322.2011.607909

Wubbels, T. (1992). Taking account of student teachers' preconceptions. Teaching and Teacher Education, 8 (2), 137-149.

Zeichner, K. (2002). Beyond traditional structures of student teaching. Teacher Education Quarterly, 29 (2), $59-64$. 